\title{
MENINGKATKAN PRESTASI BELAJAR SISWA KELAS IX DI SMP NEGERI 4 KOTA TEBING TINGGI DALAM PRAKTIK PENDALANGAN MENGGUNAKAN MEDIA NASKAH
}

\author{
Benedikta Hutabarat \\ Surel: benediktahutabarat18@gmail.com
}

\begin{abstract}
This study aims to improve the achievement of class IX students at SMP Negeri 4 Kota Tebing Tinggi in the practice of mastering using media manuscripts. Based on the results of the evaluation that has been carried out, quantitatively there is an increase in the learning achievement of students of class IX on the subject of Cultural Arts in Pedestrian Practice SMP N 4 Tebing Tinggi, both individually and in groups. The increase reached $10 \%$ to $17.33 \%$ individually, while in groups it increased to $11.83 \%$. in action (cycle) I (first). Whereas in the second (second) action (cycle) the individual increase reached between $34.28 \%$ to $46.66 \%$, and in groups increased to $35.65 \%$. Based on the data above, it can be concluded that the use of manuscript media is very effective to improve the learning achievement of class IX students in Pedal Art Skill Competency Practice Pedestal in SMP N 4 Tebing Tinggi.
\end{abstract}

Keywords: Improve learning achievement, art of mastering

\begin{abstract}
ABSTRAK
Penelitian ini bertujuan untuk meningkatkan prestasi siswa kelas IX di SMP Negeri 4 Kota Tebing Tinggi dalam praktik pendalangan menggunakan media naskah. Berdasarkan hasil evaluasi yang telah dilaksanakan, secara kwantitatif terjadi peningkatan prestasi belajar siswa kelas IX pada mata pelajaran Seni Budaya Praktik Pedalangan SMP N 4 Tebing Tinggi, baik secara individu maupun secara kelompok. Peningkatan yang dimaksud mencapai $10 \%$ sampai $17,33 \%$ secara individu, sedangkan secara berkelompok mengalami peningkatan mencapai 11,83\%. pada tindakan (siklus) I (pertama). Sedangkan pada tindakan (siklus) II (kedua) peningkatan secara individu mencapai antara $34,28 \%$ hingga $46,66 \%$, dan secara berkelompok mengalami peningkatan mencapai 35,65\%. Berdasarkan data tersebut di atas, dapat disimpulkan bahwa penggunaan media naskah sangat efektif untuk meningkatkan prestasi belajar siswa kelas IX mata pelajaran Praktek Pedalangan Kompetensi Keahlian Seni Pedalangan SMP N 4 Tebing Tinggi.
\end{abstract}

Kata Kunci : Meningkatkan Prestasi belajar, Seni pendalangan

\section{PENDAHULUAN}

Praktik Pedalangan yang merupakan salah satu mata pelajaran Kompetensi Kejuruan di Kompetensi Keahlian Seni Budaya SMP N 4 Tebing Tinggi. Esensi dari pada mata pelajaran Praktik Pedalangan adalah mengajarkan siswa untuk supaya mampu memainkan wayang dengan baik dan benar sesuai dengan aturan dan teknik -teknik tertentu berdasarkan konsep pedalangan. Akhir dari tujuan pembelajaran mata pelajaran ini setelah menuntaskan 
pembelajaran di kls IX, sesuai tujuan kompetensi keahlian seni pedalangan diharapkan siswa mampu menjadi seniman Dalang dalam tingkat madya. Dalam proses pembelajaran mata pelajaran praktek pedalangan, guru pada dasarnya menggunakan metode ceramah, tanya jawab dan demonstrasi. Bahan pelajarannya ada berbentuk Pakem. Pakem adalah buku ajaran yang memuat tentang dialog antara tokoh wayang sesuai dengan cerita lakon, yang harus dihafalkan oleh siswa. Misalnya di Kelas IX materi yang diajarkan adalah mendalang dengan lakon Arjuna Tapa demikian juga materi lakon yang lain untuk di Kelas VII dan IX. Oleh karena dalam pembelajaran praktek Pedalangan siswa selalu bergelut dengan alat yaitu Wayang, dan seperangkat pendukung lainnya seperti Cepala Keropak (kotak), dan juga gamelan, guru dalam sistem pembelajarannya lebih banyak menggunakan metode ceramah dan demonstrasi. Demonstrasi yang dimaksud adalah memberi contoh dengan peragaan, baik peragaan gerak wayang, vocal dalam bentuk tandak/sendhon dan anta wacana maupun.peragaan pukulan cepala. Dengan demikian dalam pembelajaran sudah tentu membutuhkan kesiapan siswa dalam pemahaman dan juga ingatan yang tajam untuk menghafalkan komposisi gerakan wayang demikian juga dialog/ kata-kata setiap tokoh serta alunan irama lagu/ gending. Keadaan seperti ini sering membuat siswa mengalami kesulitan dalam mengingat atau mengurutkan komposisi gerakan wayang persis seperti apa yang dicontohkan oleh guru. Karena dalam hal ini siswa hanya bisa berinteraksi jikalau guru ada di dalam kelas. Di samping itu latar belakang psikologis seperti bakat dan minat masing-masing siswa sangat berpengaruh terhadap prestasi belajar praktek pedalangan tersebut. Pada umumnya siswa yang memiliki faktor gent dari keturunan Dalang akan lebih mudah menangkap materi pelajaran dibanding siswa yang hanya bermodalkan dari minat saja. Disamping itu penggunaan metode ceramah masih mendominasi dalam pembelajaran. Proses pembelajaran adalah salah satu faktor yang mempengaruhi hasil belajar, sebab dalam proses pembelajaran akan terjadi transformasi pengetahuan. Sehingga dapat diduga rendahnya prestasi belajar siswa salah satunya disebabkan oleh kurang efektifnya proses pembelajaran yang diterapkan di dalam kelas. Berdasarkan permasalahan tersebut di atas, tampak bahwa siswa sangat memerlukan situasi belajar praktek pedalangan yang berbeda, yang bisa membuat mereka mudah memahami materi pelajaran serta mampu menerapkan materi tersebut dengan maksimal. Untuk itulah sesuai dengan prinsip "tindakan" bahwasannya guru diharapkan dapat meningkatkan kwalitas pembelajaran di kelas yang ditandai dengan meningkatnya prestasi belajar siswa, maka berdasarkan hal itulah peneliti 
memilih judul "Peningkatan Prestasi Belajar Praktek Pedalangan Siswa SMP N 4 Tebing Tinggi Dengan Penggunaan Media Naskah".

Sesuai dengan rumusan masalah tersebut, maka ditetapkan tujuan penelitiannya yaitu : Untuk mengetahui ada dan tidaknya peningkatan prestasi belajar praktek pedalangan setelah penggunaan media naskah diterapkan di Kelas IX SMP N 4 Tebing Tinggi.

\section{METODE PENELITIAN}

Dalam hubungannya dengan subyek penelitian, peneliti hendaknya dapat memilih apakah akan meneliti populasi atau sampel. Hal ini sesuai dengan pendapat Dr. Sulipan (2007:7) mengemukakan apabila peneliti meneliti semua elemen yang ada dalam wilayah peneletian, maka penelitiannya merupakan penelitian populasi. Akan tetapi jika peneliti hanya akan meneliti sebagian dari popolasi, maka disebut dengan penelitian sampel. Sampel adalah sebagian atau wakil populasi yang diteliti. Lebih lanjut dinyatakan untuk penelitian yang dilakukan guru dikelasnya, maka yang dilakukan adalah meneliti populasi, karena yang akan diteliti merupakan keseluruhan siswa di kelasnya dan tidak akan digunakan untuk generalisasi pada siswa di kelas atau sekolah lain. Dengan demikian dapat dinyatakan, untuk penelitian tindakan kelas maka yang dilakukan guru adalah meneliti populasi, dalam arti meneliti keseluruhan siswa di dalam kelas.
Berdasarkan pernyataan tersebut di atas, dalam penelitian ini, yang dijadikan subyek penelitian meliputi keseluruhan siswa Kelas IX SMP N 4 Tebing Tinggi tahun pelajaran 2016/2017, yang berjumlah 4 (empat) orang. Jumlah siswa dalam Kompetesi Keahlian Seni Pedalangan secara kwantitatif memang jauh dibawah jumlah siswa pada umumnya. Hal ini dikarenakan siswa yang memilih kompetensi pedalangan dominan mereka yang betul-betul memiliki minat dan atau bakat untuk menjadi seorang dalang. Disamping itu hal yang sangat-sangat berbeda dari kompetensi yang lain (misalnya: Seni Karawitan dan Tari) karena untuk menjadi seorang dalang harus mampu menguasai beberapa kompetensi (seperti yang tercantum pada uraian sebelumnya), dan kompetensi tersebut dibawakan atau diperagakan sekaligus dalam satu bentuk sajian lakon yaitu pertunjukan wayang. Hal inilah yang dipandang berat/sulit bagi siswa sehingga ratarata jumlah siswa di Kompetensi Keahlian Seni Pedalangan relatif kecil.

Pelaksanan tindakan akan dilaksanakan pada semester genap tahun pelajaran 2016/2017, yaitu mulai bulan April 2017. Rentang penelitian ini adalah dari bulan April sampai Mei 2017. Sejak awal Januari telah dilaksanakan perencanaan yang matang sehingga mulai bulan September tinggal melaksanakan kegiatan utama penelitian dengan optimal. Dengan rentang waktu tersebut diharapkan laporan akhir 
penelitian bisa dituntaskan pada bulan Juni sebelum liburan sekolah akhir semester genap 2017.

Penelitian ini menggunakan model Penelitian Tindakan Kelas (PTK) atau dikenal dengan Clasroom Action Research (CAR) yang dikembangkan oleh Kemmis dan Mc Taggart dari Deakin University Australia. "Penelitian Tindakan Kelas yaitu suatu bentuk penelitian yang bersifat reflektif dengan melakukan tindakan-tindakan tertentu agar dapat memperbaiki dan atau meningkatkan praktek pembelajaran di kelas secara lebih profesional". (Suyanto. dkk, 1996: 41). Model penelitian tindakan kelas ini dilaksanakan dalam dua siklus dengan mengikuti tahap-tahap penelitian tindakan dimana masingmasing siklus terdiri atas empat tahap tindakan, yaitu: perencanaan (planning), tindakan (action), evaluasi (evaluation), dan refleksi (reflection). Dalam penelitian ini, kegiatan diawali dengan studi awal/refleksi yang mengkaji ide awal yang merupakan dasar penyusunan tindakan yang dilakukan. Refleksi merupakan kegiatan perenungan atau pengkajian terhadap situasi pembelajaran yang telah dilakukan. Kegiatan ini akan melahirkan berbagai permasalahan yang ada termasuk juga keberhasilankeberhasilan yang telah dicapai. Hasil refleksi akan memberikan arah kepada peneliti untuk mengklasifikasi permasalahan yang ada dan menetapkan masalah yang hendak dipecahkan.
Observasi merupakan proses yang kompleks, suatu proses yang tersusun dari proses biologis dan psikologis. Dua diantaranya yang terpenting yaitu proses pengamatan dan ingatan" (Suharsimi, 2004:87). Jadi dapat dikatakan bahwa observasi adalah suatu proses yang kompleks, dan yang amat penting adalah proses pengamatan dan ingatan. Observasi dan penilaian yang dilakukan dalam penelitian ini adalah observasi dan penilaian terhadap pembelajaran mata pelajaran Praktek Pedalangan. Di dalam kegiatan observasi dan evaluasi ini digunakan format instrument evaluasi berupa tes praktek/unjuk kerja yang diajukan kepada siswa, serta lembar pengamatan sikap/perilaku siswa dalam mengikuti pembelajaran kemudian hasilnya dievaluasi dengan menggunakan metode deskriptif kwalitatif.

Metode Deskriptif kwalitatif dan Kreteria Keberhasilan.

Untuk memperoleh kesimpulan hasil penelitian, maka data hasil penelitian tersebut terlebih dahulu akan dianalisis. Pada penelitian ini metode analisis data yang digunakan adalah metode deskriptif kwalitatif.. Metode deskriptif ini akan menggambarkan atau memaparkan tentang pelaksanaan yang menyangkut tentang aspek-aspek pembelajaran dengan penggunaan media naskah yang dilaksanakan oleh guru kepada siswanya dalam proses pembelajaran. 
Untuk mengetahui seberapa besar kontribusi penggunaan media naskah terhadap peningkatan prestasi belajar Praktik Pedalangan siswa Kelas IX Kompetensi Kealian Seni Budaya SMP N 4 Tebing Tinggi.

\section{HASIL PENELITIAN DAN PEMBAHASAN}

Pelaksanaan pembelajaran

Praktek Pedalangan di SMP N 4 Tebing Tinggi khususnya di Kelas IX masih diwarnai oleh pola pembelajaran konvensional. Guru bertindak sebagai sumber tunggal bagi siswa selama berlangsungnya proses belajar mengajar. Kendatipun penyajian materi dilakukan oleh guru lebih didominasi oleh metode ceramah dan demonstrasi, dikarenakan memang di dalam pembelajaran praktek Pedalangan ini selalu terkait dengan alat yaitu Wayang, dan seperangkat pendukung lainnya seperti Cepala (alat pemukul keropak), Keropak (kotak), dan juga gamelan yang benar-benar membutuhkan keterampilan dan kesiapan mental yang cukup tinggi. Metode demonstrasi dalam pembelajaran praktek pedalangan yang dimaksud adalah memberi contoh dengan peragaan, baik peragaan gerak wayang, vocal dalam bentuk tandak/sendhon dan anta wacana maupun.peragaan pukulan cepala. Siswa dituntut untuk mendengarkan, memperhatikan serta menirukan apa yang disampaikan dan dicontohkan oleh guru. Selesai memperagakan contoh, guru langsung menabuh gamelan gender untuk iringan gerakan wayang, dan siswa harus mampu menirukan gerak wayang seperti yang dicontohkan oleh guru. Kelemahan metode tersebut boleh dikatakan terjadinya transfer pengetahuan dari guru ke siswa pada saat pertemuan jam pelajaran itu saja. Padahal materi pelajaran praktek pedalangan tersebut cukup sulit karena membutuhkan kesiapan mental siswa yang mencakup pemahaman, dan juga ingatan yang tajam untuk menghafalkan komposisi gerakan wayang demikian juga dialog/ katakata setiap tokoh serta kepekaan terhadap alunan irama lagu gending dan atau laras gamelan gender wayang.

Keadaan inilah sering membuat siswa mengalami kesulitan karena harus menghafal dan mengurutkan komposisi gerakan wayang yang sudah menjadi patokan atau terkontruksi persis seperti apa yang dicontohkan oleh guru terutama kepada siswa yang daya ingatnya kurang alias lemah. Disamping itu dengan metode tersebut diatas siswa hanya bisa berinteraksi jikalau guru ada di dalam kelas, selebihnya siswa dengan susah berupaya mengingatingat kembali materi yang baru saja ditransferkan oleh Guru. Kondisi seperti ini cenderung menjadikan siswa pasif padahal sesungguhnya bentuk yang cocok untuk keterampilan mental diantaranya membutuhkan bentuk diskusi dan bentuk uraian analisis.

Setelah mengetahui hasil pre tes dan sebagian siswa memperoleh 
nilai dibawah 70 (tujuh puluh) atau dibawah standar ketuntasan minimum maka langkah selanjutnya dicari faktor penyebabnya. Berdasarkan pengamatan, kelemahan siswa dalam memperagakan gerakan wayang adalah terletak pada ingatannya dalam mengurutkan komposisi gerakan wayang. Komposisi gerakan wayang kayonan yang diperagakan oleh siswa tidak sesuai dengan atau seperti apa yang dicontohkan oleh guru. Misalnya, sebelum gerakan miling seharusnya ada pengulangan gerakan milpil yang kedua dengan angsel di kiri dan kanan masing-masing satu (satu) kali. Demikian juga pada saat gerakan milpil yang pertama setelah angsel hitungan ke dua atau setelah jatuhnya gong ketika irama lagu/gending iringan meninggi (nguncab), wayang kayonan seharusnya digerakkan ngimbang atau ngombak segara dengan gerakan agak cepat, membaur mengikuti irama iringan (gender). Secara kwantitatif tindakan tahap ke dua mengalami kemajuan yang signifikan. Hal ini dikarenakan adanya perbaikan-perbaikan terhadap hal-hal yang belum dilaksanakan secara baik pada tindakan tahap pertama. Misalnya pada tindakan tahap ke dua ini yang harus benarbenar diperhatikan seperti: Ketepatan irama lagu dengan nada gamelan. Ketepatan gerak wayang dengan iringan/ gender dan penyesuaian/ keserasian gerak wayang dengan irama lagu/gending.

\section{Pembahasan}

Bila dilihat dari potensi yang dimiliki oleh siswa Kelas IX Kompetensi Keahlian Seni Pedalangan SMP N 4 Tebing Tinggi secara keseluruhan berada pada katagori baik, bahkan ada yang amat baik.. Hal ini disebabkan disamping mereka memang tekun belajar juga dipengaruhi oleh faktor keturunan Dalang sehingga mereka sangat cepat menangkap materi pelajaran. Kendatipun ada satu orang siswa yang sampai pada tindakan ke dua peningkatannya relative kecil, itu hanyalah karena faktor psykologis siswa tersebut, bukan berarti kelemahan dari faktor Guru maupun kelemahan penggunaan media naskah. Disamping itu dilihat dari segi geografis sebagian tempat tinggal siswa dengan sekolah relatif jauh. Rata-rata mereka untuk datang ke Sekolah memerlukan waktu 20 menit. Sekalipun demikian, namun prestasi belajar mata pelajaran Praktek Pedalangan masih bisa ditingkatkan. Akan tetapi karena keterbatasan waktu dan pendanaan, penelitian ini cukup pada tahap ke dua saja. Setelah dilaksanakan kegiatan siklus I (pertama), terjadi peningkatan prestasi belajar Praktek Pedalangan pada siswa Kelas IX Kompetensi Keahlian Seni Pedalangan antara $10 \%$ sampai $17,33 \%$ secara individu, sedangkan secara berkelompok mengalami peningkatan mencapai $11,83 \%$. Oleh karena di dalam penelitian tindakan ini digunakan dua siklus, dan pada tindakan pertama prestasi belajar 
dapat digambarkan seperti pada uraian di atas, maka pada siklus ke dua akan diuraikan peningkatan prestasi belajar tersebut seperti berikut: 1). Secara individu peningkatan prestasi belajar pada kegiatan siklus ke dua ini mengalami peningkatan antara $34,28 \%$ hingga $46,66 \%$, dan secara berkelompok mengalami peningkatan mencapai $35,65 \%$ jika dibandingkan dengan sebelum mendapatkan tindakan. 2). Apabila dibandingkan dengan tindakan (siklus) pertama, pada tindakan (siklus) ke dua ini, prestasi belajar secara berkelompok mengalami peningkatan juga mencapai, $23.82 \%$ (prestasi setelah tindakan tahap ke dua dikurangi tindakan tahap pertama yaitu $35,65 \%-11,83 \%=$ $23.82 \%$ ). Berdasarkan uraian di atas, dapat disimpulkan bahwa penggunaan media naskah sangat efektif untuk meningkatkan prestasi belajar Praktek Pedalangan pada siswa Kelas IX Kompetensi Keahlian Seni Pedalangan SMP N 4 Tebing Tinggi.

\section{SIMPULAN}

Dari analisis data dan pembahasan hasil penelitian dapat disimpulkan hal-hal sebagai berikut: (1) Berdasarkan hasil evaluasi yang telah dilaksanakan, secara kwantitatif terjadi peningkatan prestasi belajar siswa Kelas IX pada mata pelajaran Praktek Pedalangan Kompetensi Keahlian Seni Pedalangan SMP N 4 Tebing Tinggi, tahun pelajaran 2016/2017, baik secara individu maupun secara kelompok.

Peningkatan yang dimaksud mecapai $10 \%$ sampai $17,33 \%$ secara individu, sedangkan secara berkelompok mengalami peningkatan mencapai $11,83 \%$. pada tindakan (siklus) I (pertama). Sedangkan pada tindakan (siklus) II (kedua) peningkatan secara individu mencapai antara 34,28\% hingga $46,66 \%$, dan secara berkelompok mengalami peningkatan mencapai $35,65 \%$. Berdasarkan data tersebut di atas, dapat disimpulkan bahwa penggunaan media naskah sangat efektif untuk meningkatkan prestasi belajar siswa Kelas IX mata pelajaran Seni Budaya Kompetensi Keahlian Seni Pedalangan SMP N 4 Tebing Tinggi.

\section{DAFTAR RUJUKAN}

Ida, Herawati, Iriaji. 1991/1992. Pendidikan Seni Budaya Jakarta: UT

Muharam, E Warti Sundaryati. 1991/1992. Pendidikan Kesenian. Jakarta: UT.

Depdikbud Direktorat jendral pendidikan tinggi proyek pembinaan tenaga Direktorat pendidikan Dasar

Kusumastuti, Eny. 2010. Pendidikan Seni Tari Melalui Pendekatan Ekspresi Bebas, Disiplin Ilmu, dan Multikultular Sebagai Upaya Peningkatan Kreativitas Siswa Jurnal Harmonia. Volume X. Nomer 2: Universitas Negeri Tebing Tinggi 
Masnur. 2009. Melaksanakan PTK (Penelitian Tindakan Kelas) Itu Mudah. Jakarta: PT Bumi Aksara

Purwanto. 2013. Evaluasi Hasil Belajar. Yogyakarta: Pustaka Pelajar

Retno, Winarni. 2016. Penelitian Tindakan Kelas Salatiga.

S.R Bambang dkk. 2000. Kertangkes SMP Kelas VII. Jakarta: Erlangga.

Slamet, st.Y, Suwarto. 2007. Dasardasar Metodologi Penelitian Kualitatif. Surakarta: UNS Press.

Syaefudin, Jatmiko, Tejo, Cahyono, Agus. 2002. Pembelajaran senirupa. Jakarta: UT.

Zakarias Azis, dkk. 2016. Pendidikan Seni Direktorat Jendral Pendidikan Tinggi Kementrian Pendidikan Nasional Arikunto 